\title{
Responding to Voters or Responding to Markets? Political Parties and Public Opinion in an Era of Globalization ${ }^{1}$
}

\author{
LAWRENCE EZROW \\ University of Essex \\ AND \\ TIMOTHY HELLWIG \\ Indiana University
}

\section{Forthcoming, International Studies Quarterly}

\footnotetext{
${ }^{1}$ Authors' notes: Both authors contributed equally to this paper. Hellwig gratefully acknowledges research support from the National Science Foundation (SES-0819570 and SES-0241824), the Mellon Foundation, and the West European Studies Center at Indiana University. A previous version was presented at the 2012 Conference on Political Economy and Institutions in Baiona, Spain, and the 2012 meeting of the European Political Science Association in Berlin. The authors thank Jim Adams, John Freeman, Nathalie Giger, Marty Gilens, Kristian Gleditsch, Martin Hansen, Jonathan Homola, Nate Jensen, Andrias Jones, Scott Kennedy, Spyros Kosmidis, Gary Marks, Pedro Magalhães, Stephen Meserve, Andreas Murr, Thomas Plümper, David Sanders, Thomas Sattler, Zeynep Somer-Topcu, Nils Steiner, Paul Whiteley, and three anonymous reviewers for helpful comments on this project. A replication package can be found in the ISQ data archive.
} 
Conventional wisdom has it that political parties have incentives to respond to public opinion. It is also conventional wisdom that in open economies, policymakers must also "respond" to markets. Research on representation has provided ample evidence in support of the first claim. Research on the political economy of globalization has not, however, provided evidence for the second. This article examines the effects of globalization on how parties respond to voters. We argue that while elections motivate parties to respond to public sentiment, economic interdependence distracts political elites from their electorates and towards market actors, reducing party responsiveness to the mean voter. Evidence from a pair of distinct data sources spanning elections in twenty advanced capitalist democracies from the 1970s to 2010 shows that while parties have incentives to respond to Left-Right shifts in the mean voter position, they only do so when the national economy is sufficiently sheltered from the world economy. These findings have implications for party strategies, for representation, and for the broader effects of market integration. 
Representative democracy means that voters choose leaders to represent them in substantive terms (Pitkin 1967). In recent years several studies have put this evaluative standard to the test. Many examine the extent to which political parties respond to public preferences. On this point, the weight of the evidence finds that parties in industrialized democracies are responsive to the public's preferences (Stimson, MacKuen, and Erikson1995; Powell 2000; McDonald and Budge 2005; Soroka and Wlezien 2010), even in light of the multitude of factors pulling political actors in different directions (Tavits 2007; Adams and Somer-Topcu 2009; Meguid 2008). And while the penchant of representatives to respond to public demands may be shaped in part by electoral rules, party system polarization, party type, and the like, most studies conclude that, ultimately, democracy works.

Though edifying, this conclusion may ring hollow for citizens in many advanced capitalist democracies today. As then-Shadow Chancellor Harold Wilson's disparaging reference to financiers as "gnomes of Zurich," implies, politicians in western democracies both in and (as in Wilson's case) out of government have long struggled with how to balance public demands with the pressures of the market. In the 1970s, for instance, financial markets were hedging against Sterling as the British economy fell into recession. Pressed between fulfilling campaign promises to increase spending and requirements for receiving loans from the International Monetary Fund, the Government chose the latter. In France, the Socialist Party was swept to power in the 1980s with a mandate for nationalization and redistribution. Yet less than two years later President Mitterrand backtracked on the policies preferred by the public and embarked on a policy regime of rigueur to bring the economy in line with global capitalism. Since the 1970s and 1980s market dependencies have multiplied and deepened. In Greece, a Socialist-led government in 2009 began a process of rolling back the generous welfare state protections and entitlements popular with 
most of the electorate. In Ireland, the implosion of an asset bubble has required politicians to become attentive to bond ratings - and arguably so against the wishes of the median voter. And in Italy, attempts to dismiss the government were initially stymied. At the time, observers credited Prime Minister Berlusconi's temporary survival not to the popularity of his policies with Italian voters but to fears of speculation by globally-minded financial market actors. These examples and many others highlight instances where politicians face a choice between responding to voters and "responding" to markets.

The political implications of market dependence have not gone unnoticed. Many studies examine the consequences for policy outcomes like taxes, interest rates, or spending. Others pertain to economic performance outcomes, like income levels, or to policy preferences. And some consider how globalization affects political parties. Haupt (2010) examines economic openness and parties' policy positions, but this study does not explicitly account for shifts in the position of the median voter and how these shifts influence party positions. Adams, Haupt, and Stoll (2009) concentrate on left parties. They highlight the 'ideological' character and 'long-term policy orientations' of these parties and are thus unaffected by the position of the median voter or by globalization, and are influenced instead by their members. Ward, Ezrow, and Dorussen (2011) emphasize that the influence of globalization on parties' policy positions is conditional on the position of the median voter: that parties will adopt more rightward positions due to globalization, but only when the median voter is to the left. None of these studies, however, examine the critical questions of whether and how global economic ties influence party responsiveness to changes in voter preferences. When public opinion provides one signal and the global economy another, how do elites respond? Indeed, little research systematically examines the existence and the extent of this Catch-22. We are aware of only one study_-Broz and Hawes' (2006) study of Con- 
gressional voting as a function of "pro-globalization" constituency preferences—which bears directly on the issue of political representation.

This oversight may have much to do with a now-conventional understanding that closer ties to global markets need not compromise the actions of democratically-elected governments (e.g., Basinger and Hallerberg 2004; Clark 2003; Garrett 1998; Steinmo 2010; Swank 2002). Studies in the tradition of international and comparative political economy typically have public policy as the outcome of interest. Policy outcomes are important for understanding political control in global markets. Attention to policy outcomes, however, may well come at the expense of understanding whether and how ties to global markets influences a more fundamental tenet of representative democracy, i.e., the responsiveness of political parties to the public.

In this study we examine the effects of economic globalization on domestic politics. Our focus, however, is not on the effects of openness on government policy choices but on the position-taking strategies of political parties. We ask whether market integration compromises political parties with respect to their function of representing and expressing the political views of their electorates. We deliberately focus on the positions of political parties rather than the policies taken by governments. Parties play a unique role in aggregating public preferences channeling them into national policy debates. Parties rank as democracy's primary "channels of expression," because they "are an instrument, or an agency, for representing people by expressing their demands" (Sartori 1976, 27; italics original).

In what follows, we develop an argument about the consequences of globalization for the behavior of competing parties. Party positions are influenced by a host of economic agents, ranging from financial markets and producer groups to organized labor and consumers. With economic globalization, the range of these agents, as well as the range of pressures facing policymakers, 
increases. Globalization matters for representation because it distracts the attention of politicians from citizens and towards market actors. As a consequence, we expect the influence of globalization on representation through parties to be negative. Political parties should be less responsive to popular opinion when national economies are more exposed to world markets.

This simple but untested claim is assessed in a pair of cross-national analyses, each based on a separate data source, covering different sets of elections and utilizing different measures for party policy positions. In total, we consider connections between parties and voters in twenty developed democracies ranging from the mid-1970s to the late 2000s. We find that while parties respond to shifts in voter preferences, economic globalization reduces this responsiveness for parties with experience in government. Evidence supports the claim that exposure to trade and capital flows, as well as the consolidation of a liberal regime for international finance, suppresses party responsiveness to public opinion.

\section{Responding to Voter Preferences in World Markets}

We begin with the connections between party behavior and the wishes of the electorate. Previous research emphasizes the primacy of the median voter's policy preference as the starting point for democratic representation (Downs 1957; Huber and Powell 1994; Stimson et al. 1995; Powell 2000; McDonald and Budge 2005). Regardless of whether we assume them to be motivated by votes, office, or policy, parties have incentives to react to changes in the preferences of the median voter. Analyses of party strategies in Western Europe regularly find parties to be vote-maximizing and center-oriented. These studies characterize parties as expanding their ideologies in an attempt to appeal to a broader spectrum of the electorate. Even in instances where vote share maximization does not constitute the end goal in itself, it remains an efficient strategy 
for office- and policy-seeking parties. In the former case, increasing vote share ceteris paribus enhances the party's position for post-election coalition negotiations. ${ }^{2}$ And in the latter case, a credible assumption is that as a policy-seeking party's electoral strength increases, it gains more leverage to pull the governing coalition's policy in its preferred direction. ${ }^{3}$ In sum, be it for reasons of power, policy, or both, elections provide parties with incentives to respond to changes in the preferences of the median voter.

Globalization, however, complicates domestic politics. Much research finds this to be the case with reference to the effects of openness on social spending, tax policy, and the distribution of income (Jahn 2006; Busemeyer 2009; Bergh and Nilsson 2010; Plümper, Troeger, and Winner 2009). A basis for this complexity stems from how globalization is interpreted by political actors. By producing a new economic environment among advanced industrial states, the depth of economic integration can shift the focus of political actors from domestic to international issues. As Jahn $(2006,408)$ succinctly explains, "whereas domestic actors and conditions were the main reference points in the past, and international aspects were subordinated to domestic ones, this whole dynamic reversed in the period of increasing globalization: international factors became a major driving force for policy orientation and domestic factors became subordinated to them."

But just as globalization puts pressure on government actions, as others have argued, we maintain that it also complicates party competition. Consider once again parties' policy, office,

\footnotetext{
${ }^{2}$ Most of the political systems in the empirical analysis are multiparty and frequently yield coalition governments.

${ }^{3}$ For example, Adams and Merrill's (2009) study of parties' strategies in multiparty systems concludes that parties are motivated to adjust their policies in response to their beliefs about the median voter's position, rather than in response to the diversity of voter ideologies.
} 
and vote-based motivations. In the closed economy setting, each of these motivations provides parties with incentives to respond to voter preferences. However, with increased globalization, the standard motivations of policy, office, and vote are no longer mutually reinforcing, Responding in kind to the preferences of the median voter may remain an effective vote maximizing strategy, but only in the short term. Under globalization, party actors must extend their attention beyond voters towards an expanded number of actors and a less certain policy environment. Specifically, economic interdependence provides incentives for political elites to turn to market elites for knowledge and expertise on issues such as financial market regulations or shifting production centers. These elites, including international credit agencies, pension fund managers, and financial actors - are more informed than political elites (e.g., members of national legislatures) about how the world economy works. As a consequence, market integration increases the relevance of transnationally mobile market actors and distracts political elites from their electorates.

The influence exerted by market actors might be of little consequence if they held preferences identical to those of the median voter. But the weight of the evidence suggests otherwise. The preferences of unelected technocrats, such as those governing central banks, tend to prefer policies that privilege stability over short-term growth (cf Adolph 2013). World Bank researchers find that multinational corporations identify taxes and regulation as the greatest perceived obstacles to operating in industrial economies (Batra, Kaufmann, and Stone 2004; Broz, Frieden, and Weymouth 2008). Mosley (2003) demonstrates that the investment behavior of financial market participants is guided by a narrow range of indicators, chiefly public deficits and inflation rates. Issues which many voters care about, like public spending and labor market performance, are 
widely viewed by these actors as unimportant. ${ }^{4}$ Sanders and Tóka's (2013) examination of mass and elite opinion in 16 countries also points to a discrepancy in the views of voters and those of market actors. They find that while the public at large favors a more social model for Europe, the preferences of economic elites (e.g., managers of top economic firms) come down squarely for an "Economically Competitive Model."

Figure 1 provides one illustration of the discrepancy between the ideological preferences of market elites relative to mass publics. Collected by the IntUne project, the surveys gauge attitudes of mass publics and economic elites, as provided by the opinions of managers of top economic or financial firms, or representatives of major businesses. ${ }^{5}$ The figure compares these groups' ideological tendencies by displaying differences in the mean left-right self-placements of voters versus those of economic elites. ${ }^{6}$ Ideology is scaled so that right wing positions are higher. Positive values thus indicate that, on average, voters are located to the left of economic elites in

\footnotetext{
${ }^{4}$ This is consistent with Singer's (2011) analysis of public opinion in 39 countries in which he find that less than $2 \%$ of those surveyed responded that taxes were the most important issue in their country.

${ }^{5}$ The website associated with the "Integrated and United? A Quest for Citizenship in an Ever Closer Europe (IntUne)" project is www.intune.it. For more details about the surveys, see Best et al. 2012; Sanders et al. 2012. We do not employ the IntUne data for subsequent analyses because it is cross-sectional, and our analysis of responsiveness requires time-series cross-sectional data. ${ }^{6}$ Data are displayed for those countries that overlap between the IntUne project and our empirical coverage below.
} 
each of the ten countries that overlap with our study. ${ }^{7}$ With the exception of Italy, all of these differences are statistically significant. Moreover, they are substantively significant: in all countries (save Italy) the difference is greater than 0.5, and for Portugal, Belgium, Germany, and Denmark the mean ideological placements of economic elites are more than one full unit to the right of voters' mean placements along the 0-10 left-right scale. And in every country, the preferences of managers and business representatives are well to the right of the mean voter position. Insomuch as evidence such as this indicates a divergence of preferences between voters and markets, then the party's task of "channeling voter expression" (Sartori 1976) becomes even more difficult. ${ }^{8}$

$<$ Figure 1 about here $>$

In sum, we argue that while elections motivate parties to respond to shifts in the mean voter position, economic interdependence distracts political elites from their electorates towards market actors, adding uncertainty to the political landscape. Hence, currying favor with markets does not aid but likely weakens party incentives to respond to shifting public preferences. This argument motivates our first hypothesis:

\footnotetext{
${ }^{7}$ Hungary is the only country in the IntUne study for which voters are located to the right of economic elites.

${ }^{8}$ If market and citizen interests diverge (which we find plausible), this obviously strengthens our argument. Nevertheless we note that it is not a necessary condition for our central prediction. If globalization increases the number of politically relevant actors, as we argue, this promotes greater uncertainty in the political landscape which also reduces the likelihood that parties will respond to the mean voter.
} 
H1. Globalization Hypothesis: The responsiveness of political parties to the preferences of median voter is weaker as national economies become more exposed to world markets.

Hypothesis 1 predicts that globalization conditions responsiveness. These conditioning effects, however, are unlikely to confront all party competitors to the same degree. In multiparty democracies, many of the smaller and newer parties appeal to narrower segments of the electorate rather than to the mean voter. And many such parties have never had the responsibility of making actual policy. External considerations that could potentially influence policy, such as those arising from the world economy, are therefore less likely to play much - if any-role in the strategies of these parties. By contrast, for parties which have been saddled with the responsibility of governing, these considerations will be more salient. It may be that only after being in a position of leadership that party actors come to grips with the need to balance the preferences of the electorate with those of other actors. We examine, therefore, whether the mediating effect of globalization on party responsiveness to public opinion is more pronounced for parties with governing experience. This produces a second hypothesis:

H2. Governing Experience Hypothesis: The mediating effect of globalization on party responsiveness to public opinion is conditional on governing experience.

\section{Model, Data and Measures}

We evaluate these claims statistically by estimating a series of models examining the determinants of party behavior. If parties respond to the preferences of the mean (or median) voter, ${ }^{9}$ then they should adjust their positions on the issues as a function of shifting voter prefer-

\footnotetext{
${ }^{9}$ The empirical literature on party responsiveness generally relies on the mean voter (e.g., Adams et al. 2006). We report below that the distribution of respondents' self-placements on the 0-10
} 
ences. Levels of globalization, however, should mediate this relationship. Accordingly we specify a basic model:

$$
\begin{array}{rl}
\text { Party Shift }_{j k t}=\beta_{0} & +\beta_{1} \text { Public Opinion Shift } \\
k t & +\beta_{2} \text { Globalization }_{k t} \\
& +\beta_{3} \text { Public Opinion Shift } \\
k t & * \text { Globalization }_{k t}+\varepsilon_{j k t}
\end{array}
$$

where Party Shift $t_{j k t}$ is the change in the position of party $j$ in country $k$ at the current election $t$ compared with its position at the previous election $t-1$. Public Opinion Shift $t_{k t}$ is the change in the position of the mean voter in country $k$ at election $t$ compared with its position at election $t-1$. Globalization $_{k t}$ is a measure of country $k$ 's exposure to the international economy at time $t, \varepsilon_{j k t}$ is a disturbance, and the $\beta$ s are parameters to be estimated. ${ }^{10}$

Party policy positions have been measured using a variety of methods, including country expert assessments, assessments made by the electorate, and the coding of political party platforms. Examining the determinants of shifts in positions requires measures for a minimum of two consecutive election periods. This makes the use of expert assessments impractical. However, longitudinal measures based on the other two modes are available. We conduct two separate analyses. Our primary means of measuring party shifts is from statements from party platforms as provided by the Comparative Manifesto Project (CMP, Klingemann, Volkens, Bara, Budge, and McDonald 2006). We pair these analyses with an ancillary analysis which employs a measure of party positions produced by individuals' perceptions of the parties' locations from public opinion surveys. While such multi-measure approaches are rare in cross-national research on representation,

point left-right scale is generally unimodal and symmetric, which suggests that the mean is a close approximation to the median.

${ }^{10}$ Note that while this specification assumes a particular causal pathway, implications of plausible alternative (endogenous) relationships are also considered in the online appendix. 
our attention to the effects of globalization - a phenomenon which varies both across space and over time - makes this approach particularly attractive here. Results from each set of analyses point to the same conclusion.

Party positions and voter preferences are measured in terms of "left" and "right." The leftright scale has three attractive qualities. First, it provides a common, well-understood language of policy preferences for which data are available both for party elites and masses. Second, more than any single issue, the left-right dimension captures the primary bases of political competition across the national settings (e.g., Huber and Powell 1994; Powell 2000; see also McDonald and Budge 2005). And third, in advanced capitalist democracies the substance of "left" and "right" aligns with preferences over the government's role in the economy and the distribution of income, issues which have ranked among the most salient to voters over the past thirty-plus years (Huber and Inglehart 1995; Warwick 2002).

To capture important temporal changes in party position, we employ a panel of elections from eighteen countries ranging from 1977 to 2009. Comprised of the election manifestos from political parties in a wide range of democracies, these data provide the only cross-national estimates of party policies available for an extended time period. And since the content of party programs is often the result of intense intra-party debate, the CMP estimates should be reliable and accurate statements about parties' positions at the time of elections. Research has found these measures to be generally consistent with those from other party positioning studies, such as those based upon expert placements, citizen perceptions of parties' positions, and parliamentary voting analyses (Hearl 2001; McDonald and Mendes 2001; Laver, Benoit, and Garry 2003; see also Marks 2007). We measure left-right positions using the additive measure advocated by Laver and Budge (1992). The measure has a possible maximum value of +100 (extreme right) and a mini- 
mum of -100 (extreme left). We rescale the measure onto a $0-10$ scale. The dependent variable, Party Shift $_{j k t}$, is then measured as the change in party j's position from election $t-1$ to $t$.

Data on mean voter preferences come from a public opinion survey item that asks respondents to place themselves on a left-right scale from 1 (left) to 10 (right). ${ }^{11}$ Data for most of the cases are from the Eurobarometer surveys: Austria, Belgium, Denmark, Finland, France, Germany, Greece, Ireland, Italy, the Netherlands, Portugal, Spain, Sweden, and the United Kingdom. ${ }^{12}$ We augment this sample where possible with public opinion data for three other established democracies, Australia, New Zealand, and Norway. ${ }^{13}$ Appendix A.1, available at on our website, reports countries, elections, and parties included in the analysis.

${ }^{11}$ We recalibrate public opinion measures to fit on a $0-10$ scale.

${ }^{12}$ The first elections covered by the Eurobarometer survey series were in 1973. For each country data from these first (t-1) election years are used to create the Public Opinion Shift $t_{k t}$ variable and thus do not make up an observation in the data set. The first election year included is 1977 . Spain and Portugal were not included in the surveys until 1981 and 1986, respectively, and Austria, Finland and Sweden until 1995.

${ }^{13}$ Including (or excluding) these cases does not change the substantive findings, but it does help to broaden the sample beyond those cases included in the Eurobarometer files. Due to lack of recurrent public opinion surveys with the left-right placement measure, our sample does not include Canada, Japan, Switzerland, or the United States. The Australian data come from the Australian Election Studies data from 1987 to 2007. The New Zealand data are from the New Zealand Elections Study program for elections from 1990 to 2008. The Norwegian data in the analysis are based on Norwegian Election Studies, 1973-2005. 
For economic globalization we rely mainly on a general measure of country exposure to the world economy. The measure comes from the KOF Economic Globalization Index and combines two aspects of economic globalization: actual flows plus the absence of restrictions (Dreher 2006). ${ }^{14}$ By employing a broad indicator, we capture a range of signals pertaining to the world economy which may be received by strategic political parties. We report below additional analyses in which we substitute with other, narrower, measures. Prior to estimation, we rescale the measure from $0-100$ to $0-1$ to facilitate model interpretation. ${ }^{15}$

In order to control for the performance of the domestic economy, we include a measure of the shift in the annual per-capita growth rate from election $t-1$ to $t .{ }^{16}$ It has been shown that public support for more government policy - i.e., leftward shifts in policy positions - is greater during times of strong economic performance and declines during slow-downs (Stevenson 2001). Finally, the longitudinal nature of these data also allows us to consider the role of parties' past behav-

\footnotetext{
${ }^{14}$ The index comprised in half by flows (trade, foreign direct investment, portfolio investment, and income payments to foreigners) and half in terms of restrictions on movement (import barriers, tariff rates, taxes on trade, and capital account restrictions). See globalization.kof.ethz.ch for additional information.

${ }^{15}$ The sample mean is 0.79 , and the standard deviation is 0.11 , a minimum 0.52 (Italy 1979) and a maximum of 0.99 (Luxembourg 2004).

${ }^{16}$ Growth data is from the World Development Indicators. We also controlled for the shifts in unemployment and our substantive results remain unchanged.
} 
ior on their current policy shifts. Inclusion of Party Shift $t_{j k t-1}$ on the right-hand-side accounts for the possibility of policy alternation (Budge 1994). ${ }^{17}$

\section{Analysis and Results}

\section{Baseline Analyses}

We estimate a series of models using OLS regression. By nesting parties within countryelections, the structure of the data set gives rise to a pair of considerations which, if left unaddressed, could lead to biased and inefficient parameter estimates. First, to eliminate bias from unmeasured country-level factors which are not uncorrelated with the other explanatory variables, models are estimated with a full set of country-fixed effects. Second, it is likely that election-specific factors could affect all parties' policy shifts, and this would produce correlated errors among parties competing in the election. We address this concern by estimating heteroskedastic robust standard errors clustered by election period.

Table 1 reports model estimates. Our theory suggests that the responsiveness of parties to public opinion is contingent on economic globalization. Model 1 reports results of estimating this

\footnotetext{
${ }^{17}$ The inclusion of Party Shift $t_{j k t-1}$ also has implications for inference. Given the structure of the data, serially correlated errors within countries is also a possibility. That is, the causal processes which generate the party shift score at election $t$, could also be operating at election $t-1$. The lagged dependent variable addresses this possibility (Beck and Katz 2009). We note that while some caution against inclusion of lagged dependent variables in fixed effects models (Plümper et al. 2005), we opt to include the lagged dependent variable since it yields more conservative estimates. We note, however, that the substantive results we report below are identical or stronger when Party Shift $t_{j k t-1}$ is omitted.
} 
interactive specification for all party shifts in our sample. The estimate on Public Opinion Shift $t_{k t}$, which indicates the influence of public opinion on party shifts in a completely closed economy (Globalization $\left._{t}=0\right)$, is positive but imprecisely estimated. The estimate on the interaction term, Public Opinion Shift ${ }_{k t} *$ Globalization $_{k t}$, while carrying the expected negative sign, is also not distinguishable from zero at conventional levels. These results do not provide support for the claim that parties are systematically responsive to public opinion, nor do they show that globalization mediates the relationship between left-right shifts in public opinion and shifts in all parties' positions. Model 1 results do not support for our first hypothesis. Nonetheless, these results are illuminating: implications for the proposed mechanism can be explored by comparing estimates based on all parties to estimates based solely on parties with governing experience, namely, that the latter set of parties is more likely to have their attention diverted away from the wishes of the public when market integration increases.

$<$ Table 1 about here $>$

The second hypothesis is that the constraining effects of globalization are more pronounced for parties with governing experience. We therefore examine whether globalization conditions the strategies of those parties which have played a leading role in policy formation. We distinguish these "governing parties" from others based on if they have ever been the largest partner in a governing coalition (i.e., the chief executive or prime ministerial party). To target main parties in policy formation, the second model in Table 1 re-estimates the model only for parties with governing experience. ${ }^{18}$ The last model reports parameter estimates using only those remaining parties without governing experience.

\footnotetext{
${ }^{18}$ Parties with governing experience received an average vote share of $27 \%$; the remaining parties are much smaller, averaging 7\% share of the vote. Note that we also estimated the model on
} 
Results of these regressions highlight the importance of governing experience. In Model 2, the estimate on Public Opinion Shift $t_{k t}$ is positive and precisely estimated at $\beta_{1}=3.65$. For the case of a closed economy $\left(\right.$ Globalization $\left._{k t}=0\right)$, the model predicts that a one unit shift in the mean voter's left-right position causes the party's position to shift over three units in the same direction. Such a scenario, however, is purely hypothetical. As shown by the negative estimate on Public Opinion Shift ${ }_{k t} *$ Globalization $_{k t}(-4.55)$, the positive effect of public opinion on party behavior decreases as trans-border economic ties deepen. Thus, for parties having experienced the rigors of governing, their tendency to be responsive to the mean voter is tempered by the broader economic environment. For completeness, Model 3 results show that parties that have not governed are neither responsive to public opinion nor are their position-taking strategies affected by globalization. The difference in the magnitude of the reported estimates on the interaction term in Models 2 and 3 is statistically significant. ${ }^{19}$ All told, these findings provide solid parties with any sort of experience in government (chief executive or junior coalition partner). For this larger set of cases $(n=398)$, the parameter estimate on the interaction term is in the expected negative direction but does not attain statistical significance for any in-sample value of Globalization.

${ }^{19}$ To assess this, we estimated a model with all cases but with a three-way interaction variable:

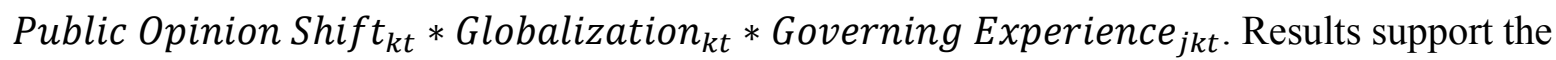
finding that the mediating effects of globalization are much stronger for parties with governing experience than for those without (the coefficient on triple interaction term is: $-6.13 ; p=.001$ ). A joint $F$ test reveals that conditioning globalizations' influence on party type in this way is also statistically significant $(F=4.07, p=0.01)$. 
support for The Governing Experience Hypothesis: the constraining effects of economic globalization are more pronounced for parties with governing experience than for other parties.

Table 1 regression models only provide information about the effect of public opinion on party left-right strategies for two instances: where Globalization Gt $_{\text {equals }} 0$ or when it equals 1. Accordingly, Figure 2 uses Table 1 Model 2 estimates to chart the marginal effects of public opinion shifts on party shift across the sample range of values for economic globalization. The negative slope indicates that as globalization increases, the estimate of party responsiveness to the mean voter position decreases. The coefficient on Public Opinion Shift $t_{k t}$ attains statistical significance when Globalization $_{k t}$ is below 0.70 on the $0-1$ rescaled index. In the remainder of cases - those more exposed to trade, capital flows and employing more liberal policies-our model estimates that changes in public opinion, as represented by the mean voter, have no statistically significant influence on party shifts.

$<$ Figure 2 here $>$

To facilitate interpretation of the results, we briefly consider the case of France, a country which has grappled considerably with the wider political effects of globalization. In 1988, the French economy was, vis-à-vis many of its European neighbors, relatively closed from international trade and capital flows. At this time, France's KOF Globalization index equaled 0.57. At such a level of globalization, in terms of Model 2 estimates, the conditional coefficient on the Public Opinion Shift $t_{k t}$ variable is $1.06([(1 * 3.65)-(.57 * 4.55)]=+1.06)$. This impact of public opinion substantively significant: when the mean voter's position shifts by .30 units along the $0-10$ scale, which represents the inter-quartile range of the public opinion shift data, the governing experience parties' left-right positions tend to shift by over 6 units in the same direction along the 200-point left-right CMP scale. By the time of the 2007 election, the economy 
had opened up considerably, with a KOF Globalization index of 0.75 . Given this level of integration, our model no longer predicts a systematic relationship between shifts in public opinion and shifts in the positions of such parties with governing experience as the French Socialists or Gaullists. The conditional coefficient on the Public Opinion Shift ${ }_{k t}$ variable is also much smaller $([(1 * 3.65)-(.75 * 4.55)]=+.24)$, an estimate which suggests that governing experience parties' left-right positions tend to shift by less than 1.5 in the same scenario described above.

\section{Additional Analyses}

We explored several alternative contingencies and measures to establish the robustness of our statistical results. One distinction which has received much attention is the behavior of niche parties, that is, parties which limit their issue appeals and which do not face a trade-off between advocating their preferred policy beliefs and moderating policies to maximize electoral support (Adams, Clark, Ezrow, and Glasgow 2006; Meguid 2008). It may be that the governing experience effect shown in Table 1 is picking up a "mainstream" effect, i.e., globalization may only affect parties belonging to the Social Democratic, Conservative, Christian Democratic, or Liberal party families. ${ }^{20}$ We examine this conjecture by estimating models to test whether the parameters on the interaction term, $\beta_{3}$ in equation (1), is statistically different for mainstream and niche parties. Unlike the governing experience distinction, the mainstream/niche distinction is found to have no effect. We also examined whether results were driven by left- and right-of-

\footnotetext{
${ }^{20}$ Mainstream and governing experience classifications are not synonymous: while nearly all parties with executive experience are mainstream, $48 \%$ of mainstream parties in our sample have no experience heading up governments.
} 
center parties and by centrist relative to extremist parties. None of these distinctions matter to the degree that governing experience does. ${ }^{21}$ These non-findings bolster our argument that politicians that have headed governments are more distracted by market integration than politicians of other parties. (We report these analyses in the online appendix).

Second, we consider the direct effects of globalization on party behavior. If, as Figure 1 implies, the preferences of market actors lie to the right of the average voter's preferences, then we might expect increasing globalization to shift parties to the right, to more neoliberal policy positions. A definitive test of this claim would require us to incorporate measures of economic elites' preferences into our model. Unfortunately, such data are unavailable for a sufficient number of cases. We can, however, examine whether increasing globalization influences party shifts directly. Model 1 in Table 2 presents these results by including the inter-election shift in globalization on the right hand side $\left(\Delta\right.$ Globalization $\left._{k t}\right) .{ }^{22}$ The parameter estimate is positive, indicating that parties tend to shift to the right when market integration increases. Our substantive results, however, remain unchanged. This result is consistent with the argument that if increasing globalization motivates political elites to place greater weight on economic elites' policy preferences at the expense of the voters', and if the preferences of economic elites are to

${ }^{21}$ In none of these cases do the $F$ tests of the joint significance of public opinion shift, globalization, and party type achieve statistical significance. For the interactive model distinguishing mainstream parties from niche parties, $F=0.98, p=0.40$; for left parties versus non-left, $F=$ $2.04, p=0.11$; for right parties versus non-right, $F=1.46, p=0.23$; and for center versus extreme, $F=1.11, p=0.40$.

${ }^{22}$ The marginal effects for these and subsequent analyses reported in this section are presented in Appendix Figure A1. 
the right of the mass public, then increasing globalization should motivate parties to shift to the right.

$<$ Table 2 about here $>$

Third, we consider alternative globalization indicators. In pooling information on a range of flows and policy decisions, the KOF Economic Globalization Index used in Table 1 provides a broad set of signals about the world economy's reach. Yet different components of globalization may have different effects on political outcomes. Is this the case for party responsiveness? To investigate this issue, we re-estimated Table 1 Model 2 separating out Dreher's indices of flows and restrictions. Flows incorporate information on imports and exports of goods and services, foreign direct investment, portfolio investment, and income payments to foreign nationals. Restrictions includes information on hidden import barriers, mean tariff rates, import and export duties and other taxes on international trade, and capital account restrictions. ${ }^{23}$ Models 2 and 3 of Table 2 report estimates for flows and restrictions. Substituting these series for the more general globalization measure produces no change in the relationship of interest. Model 4 further narrows the focus by looking at trade openness alone. Results again confirm our initial findings. Our substantive conclusions again remain unchanged.

A fourth consideration pertains to over-time trends. Exposure of national economies to flows from abroad has generally, though not always, increased with time. Thus, we might be concerned that what appears as a globalization effect may simply be capturing a secular decline

\footnotetext{
${ }^{23}$ Lower values on these restrictions contribute to higher values on the index, this reflecting greater liberalization.
} 
in parties' tendencies to respond to public opinion. ${ }^{24}$ To address this concern, we perform a pair of supplemental analyses. First, we re-estimated the parameters of the basic model specification including an election year variable to control for time. Secondly, we purged the globalization index of the time element by regressing it on election year. The residuals from this model were then used as a 'de-trended' measure of economic globalization in the basic specification. In both cases, shown in Table 2 Models 5-6, the results support the same conclusions as above.

Fifth, results reported here might not be due to globalization but to the fact that in many European Union member states, political parties in government are formally bound to a more limited set of credible policy options. By including in the dataset countries that are in and outside of the EU, we have in part already diffused this concern (see also below). However, if it can be shown that economic globalization reduces party tendencies to shift positions in response to public opinion within EU member states, then we can take this as evidence that despite limits on their jurisdictional competence, variation with respect to economic globalization is driving weaker responsiveness rather than some aspect shared by all Member States (i.e., "Europeanization"). To examine this conjecture, Table 2 Model 7 reports model estimates for EU members only. Results do not change from those produced by the entire sample. ${ }^{25}$

Finally, there is the question of concept measurement. One historical problem with measuring party positions using the CMP data is that the estimates of party position have not been

\footnotetext{
${ }^{24}$ For example, the professionalization of election campaigns may cause parties to downplay their responsiveness on policy grounds in favor of emphasizing other qualities with respect to party image or candidates for office.

${ }^{25}$ Note that we also attempted to examine the effects for countries that joined the Eurozone (1999 or later) but could not due to degrees of freedom constraints.
} 
published with corresponding estimates of uncertainty (Benoit, Laver, and Mikhaylov 2009). If a party "shifts" two units based on the CMP estimates, for example, but the uncertainty around the estimate is five units, then it is possible that the party did not shift in fact shift position at all. One way to address this concern, and consider the implications of uncertainty, is to estimate the parameters of the model specification for Table 1 Column 2 for only significant party shifts, i.e., shifts that are greater than the bootstrapped standard errors published by Benoit et al. (2009). ${ }^{26}$ Table 2 Model 7 reports estimates for only significant party shifts. The estimates based on a limited number of observations (156 from 252) support our substantive results.

\section{Analyses Based on Comparative Study of Electoral Systems Data}

We re-evaluated the findings above relying on data from Modules 1-3 of the Comparative Study of Electoral Systems (CSES). Where possible we supplemented these cases with data from separate national election studies. For example, the CSES modules included the 1996 and 2002 elections in New Zealand. Without data from the 1999 vote, however, information from these cases could not be included in the case selection. We merged in data from the intervening 1999 New Zealand Election Study. ${ }^{27}$ In total, measures were constructed for parties' policy ad-

\footnotetext{
${ }^{26}$ See http://www.kenbenoit.net/cmp/cmp-error/.

${ }^{27}$ Recall that data from two consecutive elections are required. We similarly supplemented measures from the intervening 2000 Australian, 2001 British, and 2007 Irish post-election surveys. For ease, we refer to the combination of these with the CSES modules as the "CSES-based" analyses.
} 
justments for 79 parties in 46 national elections in 15 countries between 1999 and 2009 (see online Appendix A.2). ${ }^{28}$

Apart from mere replication purposes, this supplementary analysis is beneficial for three reasons. First, it offers us a different way of measuring the dependent variable, party shift, by using information from respondent perceptions of party positions rather than relying on party programs. Second, in covering the period 1999-2009, this analysis provides an additional check against barriers to inference owing to time effects. And third, cases included in this dataset arguably provide a varied mix of experiences; for example, seven of the 15 countries are outside the eurozone.

In each survey, respondents were asked to place parties on the left-right scale: "In politics people sometimes talk of left and right. Where would you place [PARTY] on a scale from 0 to 10 where 0 means the left and 10 means the right?" The mean value of all responses to this item in a given election survey constitutes the parties' overall left-right policy stance. Our measures of public opinion also come from the supplemented CSES data. As above, we use the overall mean of survey respondents' self-placement on the 0-10 point left-right scale at the time of the election.

${ }^{28}$ The 2004 Japanese election is omitted due to the absence of data on party positions. We also omit the 2004 Spanish election for reasons both empirical and substantive. Empirically, the mean voter shift in our dataset is nearly twice as great in magnitude as any other in the sample $(-0.56$, the next greatest being -0.34 for Iceland in 2009). This drastic leftward shift can be readily understood in the context of the vote, which occurred just three days after the Madrid train bombings by terrorists, and action that removed the governing Partido Popular from power and gave an unexpected victory to the center-left (for evidence of unexpected nature of this result, see Bali 2006; Montalvo 2012). 
Model 8 of Table 2 reports results of this analysis, based, as previously, on governing experience parties. ${ }^{29}$ Results continue to support our finding that governing parties' responsiveness to public opinion is mediated by levels of globalization. The marginal effects of the coefficient on Public Opinion Shift $t_{k t}$ are reported in Figure 3. The similarity between Figures 2 and 3 is remarkable in light of differences in measures of party position, sets of countries, and time-periods. The confidence in the reported findings is increased by leveraging these two independent sets of data and employing different measures of party position.

$<$ Figure 3 here $>$

\section{Conclusion}

"Can we still have the highest taxes when people more and more notice that you get a better salary after taxes if you move to London? Our social security system, can it survive? It gets harder with globalization. [Our party] has had big discussions on how we are influenced by politics abroad." -- Liberal Party Member of the Danish Folketing ${ }^{30}$

While parties have incentives to respond to public opinion, we show they do so only when the national economy is sufficiently sheltered from world markets. As countries become more deeply integrated into world markets, party representatives appear less and less responsive to citizen preferences. Specifically, we find that, all else equal, parties with governing experience in countries characterized by high levels of economic globalization do not respond in kind to interelection shifts in the mean voter's positions in terms of left and right. This central finding holds,

${ }^{29}$ The model includes the same measures for globalization and growth as used previously. Due to the lack of three consecutive elections in all but a few cases, we are unable to include lagged party shifts.

${ }^{30}$ Interviewed in Copenhagen, March 20, 2003. 
drawing on not one but two cross-national data sets. It holds when we rely on different definitions of economic globalization, in a variety of countries, over different time periods, and for different measurements of party positions. These results support our argument that globalization enhances the political relevance of market actors over voters, distracting political elites from the electorate.

These results have fundamental implications for policy responsiveness in advanced industrial democracies. It is important, however, to be clear about what we have not shown. First, we do not provide evidence that parties fail to respond in kind to voter shifts over intervals more abrupt than the inter-election period. ${ }^{31}$ Second, we do not provide evidence that globalization diminishes responsiveness to other groups of the electorate beyond the preferences of the mean voter. And third, our findings do not provide evidence that globalization affects party responsiveness on other issues dimensions beyond left-right or, for that matter, on individual issue positions.

This study raises many questions and opens several avenues for future research. The first pertains to the issue of responsiveness. While previous studies debate globalization's effect on policy convergence (e.g., Garrett 1998; Jahn 2006) or on party positions (e.g., Haupt 2010; Ward et al. 2011), this study is the first to demonstrate the conditioning effect of globalization on mean voter responsiveness. The emphasis on the mean voter position is consistent with prominent re-

\footnotetext{
${ }^{31}$ This limitation applies to the vast majority of empirical studies of party responsiveness. Analyses of party responsiveness to year-to-year shifts in public opinion remain rare, due chiefly to the lack of available measures of changes in party preferences from one year to the next. Some have overcome this challenge by measuring party preferences through the coding of speeches (e.g., Hobolt and Klemmensen 2008).
} 
search that also emphasizes the role of the mean voter as the starting point for democratic representation (e.g. Downs 1957; McDonald and Budge 2005; Powell 2000; Stimson et al. 1995). Although the use of the mean voter is justified by a long tradition of research in spatial modeling and public opinion research which holds that capturing the preferences of the mean (or median) is fundamental to the party's electoral success, to the extent that issue preferences among the electorate vary or are "multi-peaked" then future studies should examine party responsiveness to specific groups within the electorate, such as opinion leaders (e.g., Adams and Ezrow 2009), high sophisticates (e.g., Gomez and Wilson 2001), or high-income earners (e.g., Bartels 2008). It may well be that by creating new groups of "winners" and "losers" (Rodrik 1997), globalization creates incentives for parties to appeal to specific groups on which their success most depends.

A second question pertains to how scholars conceive of substantive representation (Pitkin 1967). Our use of the left-right superdimension as a summary of voters' preferences is deliberate: In established party systems, the language of "left" and "right" summarizes issue positions better than any other. But it is also possible that globalization contributes to a reduction in the relative saliency of the left-right dimension. With respect to this point, scholars have emphasized the relevance of an additional issue dimension. As evinced by its labels of green/alternative/libertarian traditional/authoritarian/nationalism (Marks, Hooghe, Nelson, and Edwards 2006) and integration-demarcation (Kriesi, Grande, Lachat, Dolezal, Bornschier, and Frey 2008), the salience of this alternative structuring dimension may be associated with economic globalization. Insights from this research on the multidimensional nature of party competition in advanced capitalist democracies should be incorporated into future research on the determinants of party responsiveness. 
Thirdly, in showing how globalization's impact is driven by parties with executive experience, this study adds to and advances scholarship on the diversity of party strategies. As others have shown, when it comes to mean voter responsiveness, all parties are not the same (Adams et al. 2006; Adams and Ezrow 2009). Particularly relevant is Andrews and Money's (2009) distinction between "champions" and "challengers" - that is, parties that have been a part of a governing coalition at one time and those that have not. Andrews and Money (2009) find that challengers gain votes by adopting a strategy of policy extremism, while champions enhance their electoral support via a strategy of policy moderation. To the extent that we employ a similar typology that stratifies parties based on governing experience, it suggests that economic globalization constrains champions from responding to shifts in the mean voter position, and that challengers are not similarly constrained.

Fourthly, a similar analysis is in the offing of policy outcomes and, in particular, whether the election promises of parties are implemented. ${ }^{32}$ Research on policy responsiveness finds that the preferences of the median voter work through parties' policy positions to affect levels of public spending (Kang and Powell 2010). Naurin (2011: Chapter 4) similarly finds that governing parties, on the whole, do tend to carry out their campaign promises if they are fortunate enough to reach government. Although our study suggests that globalization mediates (diminishes) these linkages - from citizen preferences to public policy, or from campaign promises to enacted policy_direct analysis of them would be worthwhile. ${ }^{33}$

\footnotetext{
${ }^{32} \mathrm{We}$ acknowledge a reviewer for raising the point that economic globalization may specifically influence the ability of governing parties to implement their election promises.

${ }^{33}$ In the online appendix, we present evidence that suggests globalization conditions the influence of public opinion shifts on policy outcomes.
} 
Our empirical findings represent a crucial step for understanding the linkage between public opinion and party ideologies, under different levels of market integration. While we now know a great deal about the extent to which trade and capital flows shape public spending and policy choices, there is much work to be done on globalization and "politics" more broadly defined. We thus agree with Kayser $(2007,341)$ that "the sheer volume" of literature on globalization has made it easy to overlook the fact that "very little of it addresses the effect of economic globalization on actual politics." In this contribution, we have provided evidence that political parties with governing experience do not respond systematically to citizen demands in open economies. 


\section{References}

Adams, James, Michael Clark, Lawrence Ezrow, and Garrett Glasgow. (2006) Are Niche Parties Fundamentally Different from Mainstream Parties?: The Causes and Electoral Consequences of Western European Parties' Policy Shifts, 1976-98. American Journal of Political Science 50(3): 513-529.

AdAms, James, AND LAWrence EzRow. (2009) Who do European Parties Represent? How Western European Parties Represent the Policy Preferences of Opinion Leaders. Journal of Politics 71(1): 206-223.

Adams, James, Andrea Haupt, And Heather Stoll. (2009) What Moves Parties? The Role of Public Opinion and Global Economic Conditions in Western Europe. Comparative Political Studies 42(5): 611-39.

Adams, James, And Samuel Merrill, III. (2009) Policy-Seeking Parties in a Parliamentary Democracy with Proportional Representation: A Valence-Uncertainty Model. British Journal of Political Science 39(3): 539-558.

Adams, James, And ZeyneP Somer-Topcu. (2009) Policy Adjustment by Parties in Response to Rival Parties' Policy Shifts: Spatial Theory and the Dynamics of Party Competition in Twenty-Five Post-War Democracies. British Journal of Political Science 39(4): 825-846.

Adolph, Christopher. (2013) Bankers, Bureaucrats, and Central Bank Politics: The Myth of Neutrality. Cambridge: Cambridge University Press.

Andrews, Josephine T., AND Jeannette Money. (2009) The Spatial Structure of Party Competition: Party Dispersion within a Finite Policy Space. British Journal of Political Science 39(4): 805-824. 
BALI, VALENTINA. (2006) Terror and elections: Lessons from Spain. Electoral Studies 26(3): 669-87.

BARTELS, LARry M. (2008) Unequal Democracy: The Political Economy of the New Gilded Age. Princeton, NJ: Princeton University Press.

Basinger, Scott J., AND Mark Hallerberg. (2004) Remodeling the Competition for Capital: How Domestic Politics Erases the Race to the Bottom. American Political Science Review 98(2): 261-76.

Batra, Geeta, Daniel Kaufmann, And Andrew H. W. Stone. (2004) The Firms Speak: What the World Business Environment Survey Tells Us about Constraints on Private Sector Development. Microeconomics 0405004, EconWPA.

Bean, Clive, David Gow, And Ian McAllister. 2004. Australian Election Study, 2001, [computer file]. Canberra: Australian Social Science Data Archive, The Australian National University.

Beck, Nathaniel, And Jonathan N. Katz. (2009) Modeling Dynamics in Time-Series Cross-Section Political Economy Data. California Institute of Technology Social Science Working Paper 1304.

BERGH, AdREAS, AND THERESE NILSSON. (2010) Do Liberalization and Globalization Increase Income Inequality? European Journal of Political Economy 26(4): 488-505.

Benoit, Kenneth, Michael Laver, And Slava Mikhaylov. (2009) Treating Words as Data with Error: Uncertainty in Text Statements of Policy Positions. American Journal of Political Science 53(2): 495-513. 
Best, Heinrich, György Lengyel, And LuCA Verzichelli, Eds. (2012) The Europe of Elites. A Study into the Europeanness of Europe's Economic and Political Elites. Oxford: Oxford University Press.

Broz, J. LAWREnCe, JefFry Frieden, AND StePhen Weymouth. (2008) Exchange Rate Policy Attitudes: Direct Evidence from Survey Data. IMF Staff Papers 55(3): 417-444.

Broz, J. Lawrence, And Michael Brewster Hawes. (2006) Congressional Politics of Financing the International Monetary Fund. International Organization 60: 367-399.

Budge, IAn. (1994) A New Theory of Party Competition: Uncertainty, Ideology, and Policy Equilibria Viewed Temporally and Comparatively. British Journal of Political Science 24: 44367.

Busemeyer, Marius R. (2009) From Myth to Reality: Globalisation and Public Spending in OECD Countries Revisited. European Journal of Political Research 48(4): 455-482.

Clark, William Roberts. (2003) Capitalism Not Globalism. Ann Arbor, MI: University of Michigan Press.

Clarke, Harold D., Marianne C. Stewart, David Sanders, and Paul F. Whiteley. (2003) British General Election Study, 2001; Cross-Section Survey [computer file]. Colchester, Essex: UK Data Archive [distributor], SN: 4619.

Downs, AnTHONy. (1957) An Economic Theory of Democracy. New York: Harper.

DreHER, AXEL. (2006) Does Globalization Affect Growth? Evidence from a new Index of Globalization. Applied Economics 38(10): 1091-1110.

Garrett, Geoffrey. (1998) Partisan Politics in the Global Economy. New York: Cambridge University Press.

Gomez, Brad T., AND J. MattheW WiLson. (2001) Political Sophistication and Economic 
Voting in the American Electorate: A Theory of Heterogeneous Attribution. American Journal of Political Science 45: 899-914.

Haupt, Andrea B. (2010) Parties' Responses to Economic Globalization. Party Politics 16(1): 5-27.

Hearl, DereK. (2001) Checking the Party Policy Estimates: Reliability. In Mapping Policy Preferences: Estimates for Parties, Electors, and Governments 1945-1998, edited by Ian Budge, Hans-Dieter Klingemann, Andrea Volkens, Judith Bara, and Eric Tanenbaum, Oxford: Oxford University Press, 111-125.

Hobolt, Sara B., And Robert KLemmensen. (2008) One for All, All for One: Issue Competition in Party Leader Rhetoric. Paper presented at the annual meeting of the Midwest Political Science Association.

Huber, John D, And Ronald Inglehart. (1995) Expert Interpretations of Party Space and Party Locations in 42 Societies. Party Politics 1(1): 73-111.

Huber, John D. AND G. Bingham Powell, JR. (1994) Congruence Between Citizens and Policymakers in Two Visions of Liberal Democracy. World Politics 46(3): 291-326.

JAHn, DeTLEF. (2006) Globalization as 'Galton's Problem': The Missing Link in the Analysis of Diffusion Patterns in Welfare State Development. International Organization 60: 401-431.

Kang, Shin-Goo. And G. Bingham Powell, JR. (2010) Representation and Policy Responsiveness: The Median Voter, Election Rules, and Redistributive Welfare Spending. Journal of Politics 72(4): 1014-28.

Kayser, Mark Andreas. (2007) How Domestic is Domestic Politics? Globalization and Elections. Annual Review of Political Science 10: 341-62. 
Klingemann, Hans-Dieter, AndReA Volkens, Judith Bara, IAn Budge, And Michael D. MCDonALD. (2006) Mapping Policy Preferences II: Estimates for Parties, Electors and Governments in Central and Eastern Europe, European Union and OECD 1990-2003. Oxford: Oxford University Press.

Kriesi, Hanspeter, Edgar Grande, Romain Lachat, Martin Dolezal, Simon Bornschier, Timotheos Frey. (2008) West European Politics in the Age of Globalization. Cambridge: Cambridge University Press.

Laver, Michael, Kenneth Benoit, And John Garry. (2003) Extracting Policy Positions from Political Texts Using Words as Data. American Political Science Review 97: 311-31.

Laver, Michael, And Ian Budge, Eds. (1992) Party Policy and Coalition Policy in Europe. London: Macmillan.

Marks, Gary, Liesbet Hooghe, Moira Nelson, and Erica E. Edwards. (2006) Party Competition and European Integration in East and West Europe: Different Structure, Same Causality. Comparative Political Studies 39(2): 155-179.

MARKS, GARY, Ed. (2007) Special Issue: Estimating Error in Measures of Party Position ing. Expert, Manifesto and Survey Data Compared. Electoral Studies 26(1):1-141.

MARSH, MichAEL, AND RichARD SinNOTT. (2008) Irish National Election Study 2002-2007 [Computer File]. Dublin: Trinity College.

McDonald, Michael, And Ian Budge. (2005) Elections, Parties, and Democracy: Conferring the Median Mandate. Oxford: Oxford University Press.

McDonald, Michael, And Sylvia Mendes. (2001) Checking the Party Policy Estimates: Convergent Validity. In Mapping Policy Preferences: Estimates for Parties, Electors, and Gov- 
ernments 1945-1998, edited by Ian Budge, Hans-Dieter Klingemann, Andrea Volkens, Judith Bara, and Eric Tanenbaum, Oxford: Oxford University Press, 127-142.

Meguid, Bonnie. (2008) Party Competition between Unequals. Cambridge: Cambridge University Press.

Montalvo, Jose G. (2012) Re-examining the evidence on the electoral impact of terrorist attacks: The Spanish election of 2004. Electoral Studies 31(1): 96-106.

Mosley, Layna. (2003) Global Capital and National Governments. New York: Cambridge University Press.

Naurin, Elin. (2011) Election Promises, Party Behaviour and Voter Perceptions. Basingstoke: Palgrave Macmillan.

PitKin, Hanna. (1967) The Concept of Representation. Berkeley: University of California Press.

Plümper, Thomas, Vera Troeger, And Philip Manow. (2005) Panel Data Analysis in Comparative Politics: Linking Method to Theory. European Journal of Political Research 44(2): $327-354$.

Plümper, Thomas, Vera E. Troeger, And Hannes Winner. (2009) Why is There No Race to the Bottom in Capital Taxation? International Studies Quarterly 53(3): 761-786.

Powell, G. Bingham. (2000) Elections as Instruments of Democracy. New Haven: Yale University Press.

RoDRIK, DANI. (1997) Has Globalization Gone Too Far? Washington, DC: Institute for International Economics. 
SANDERs, DAVid, PAOlo Bellucci, GÁBor TóKa, AND Mariano Torcal, Eds. (2012) The Europeanization of National Polities? Citizenship and Support in a Post-Enlargement Union. Oxford: Oxford University Press.

SANDERS, DAVID, AND GÁBOR TÓKA. (2013) Is Anyone Listening? Mass and Elite Opinion Cueing in the EU. Electoral Studies 32(1): 13-25.

Sartori, Giovanni. (1976) Parties and Party Systems. New York: Cambridge University Press.

Schmitt, Hermann, AND Evi Scholz. (2005) The Mannheim Eurobarometer Trend File, 1970-2002 [Computer file]. Cologne, Germany: Zentralarchiv fur Empirische Sozialforschung.

Singer, MATTHEW M. (2011) Who Says 'It's the Economy'? Cross-National and CrossIndividual Variation in the Salience of Economic Performance. Comparative Political Studies 44(3): 284-312.

Soroka, StuArt, And Christopher WLeZIEn. (2010) Degrees of Democracy: Politics, Public Opinion, Policy. Cambridge: Cambridge University Press.

Steinmo, Sven. (2010) The Evolution of Modern States: Sweden, Japan and the United States. New York: Cambridge University Press.

Stevenson, Randolph T. (2001) The Economy and Policy Preference: A Fundamental Dynamic of Democratic Politics. American Journal of Political Science 45(3): 620-633.

Stimson, James, Michael MacKuen, And Robert ERiKson. (1995) Dynamic Representation. American Political Science Review 89: 543-565.

Swank, Duane. (2002) Global Capital, Political Institutions, and Policy Change in Developed Welfare States. New York: Cambridge University Press. 
TAvits, Margit. (2007) Principle versus Pragmatism: Policy Shifts and Political Competition. American Journal of Political Science 51(1): 151-165.

Ward, Hugh, LAWrence EzRow, AND Han Dorussen. (2011) Globalization, Party Positions, and the Median Voter. World Politics 63(3): 509-547.

Warwick, PAUl V. (2002) Toward a Common Dimensionality in West European Policy Spaces. Party Politics 8: 101-122. 
Figure A1: Conditional Effects Graphs, corresponding to Models 1-7 in Table 2
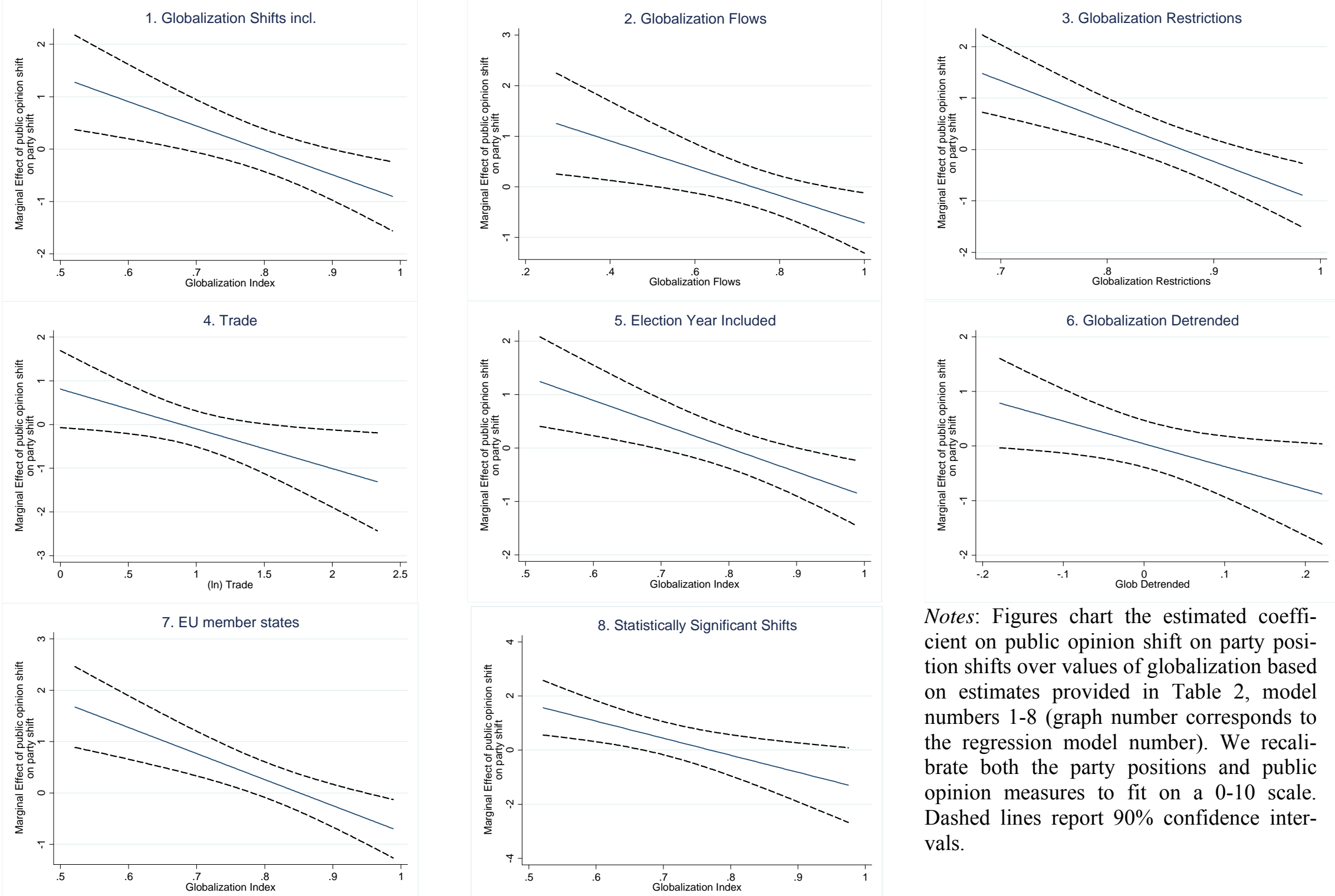

Notes: Figures chart the estimated coefficient on public opinion shift on party position shifts over values of globalization based on estimates provided in Table 2, model numbers 1-8 (graph number corresponds to the regression model number). We recalibrate both the party positions and public opinion measures to fit on a $0-10$ scale. Dashed lines report $90 \%$ confidence intervals. 
Figure 1. Ideological Bias between Economic Elites and Mass Publics, 2007

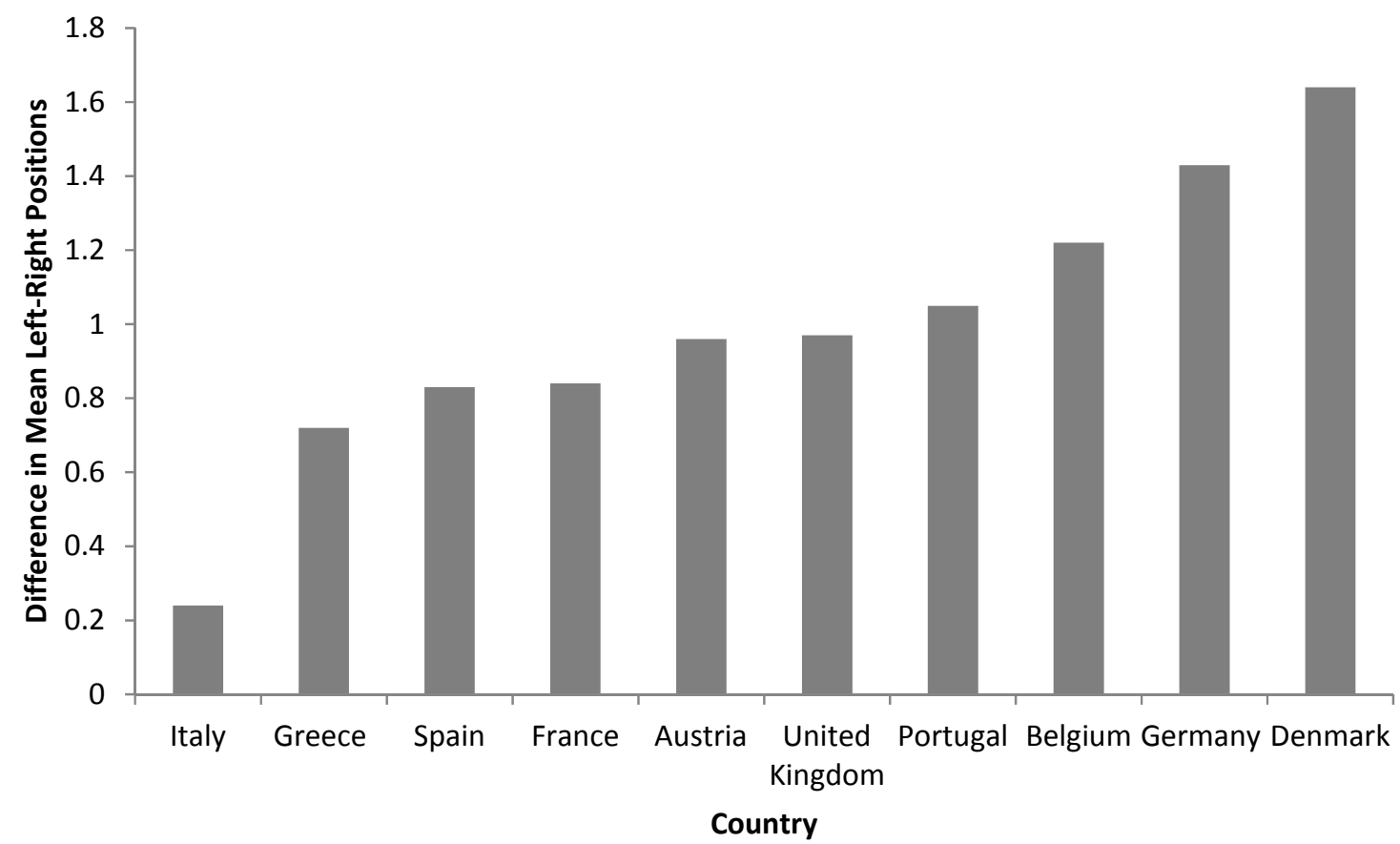

Notes. Data are from the IntUne project (www.intune.it). Columns report the mean selfplacements of economic elites minus the mean self-placement in the electorate, on a 0-10 LeftRight scale. Positive values indicate that economic elites are, on average, more right-wing than the electorate. Based on the difference of means tests, all of the differences are statistically significant at the .05 level, except for Greece $(p=.07)$ and Italy $(.30)$. 
Figure 2. Effect of Public Opinion Shift on Party Shift Conditional on Economic Globalization for Parties with Governing Experience

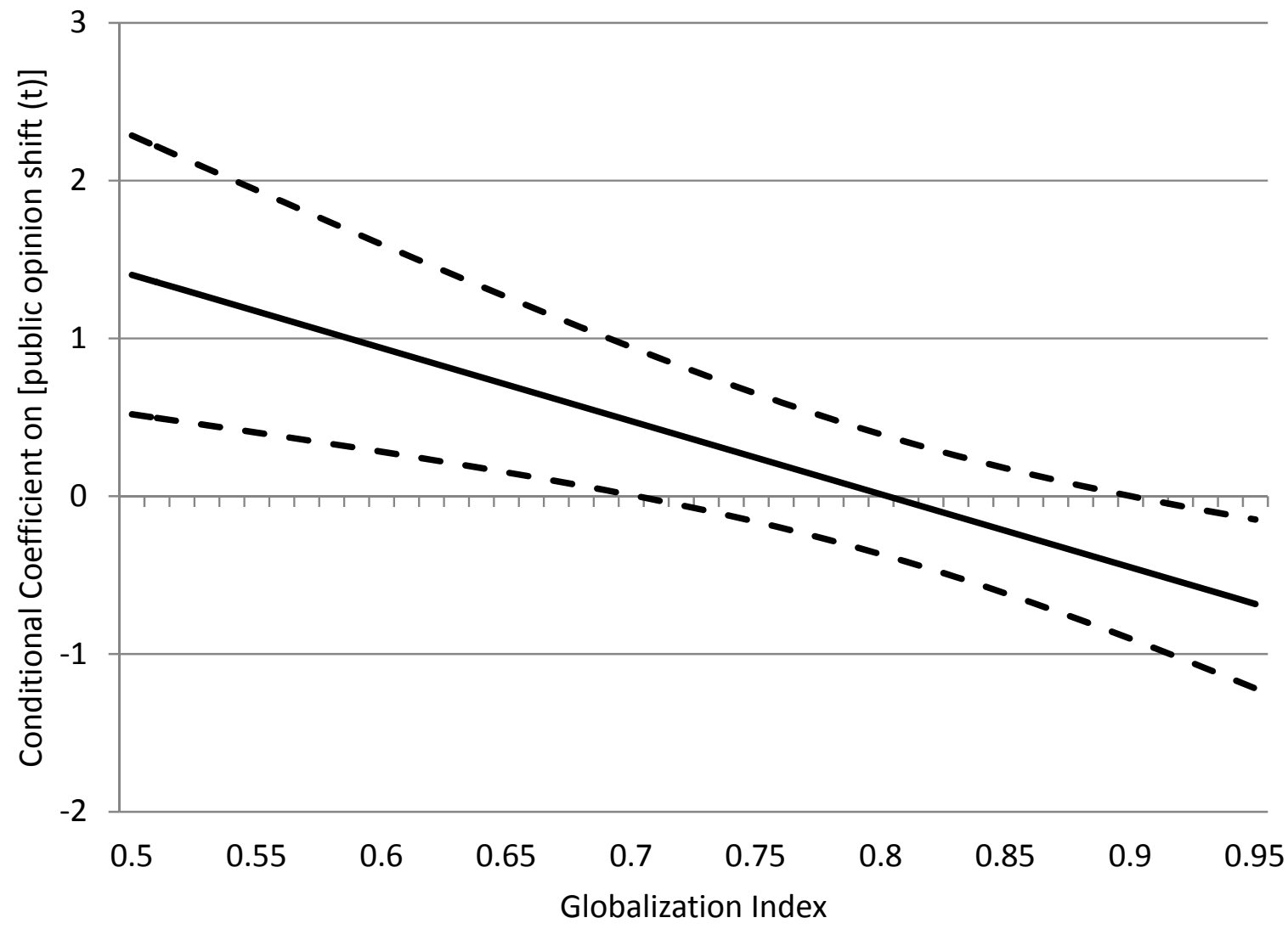

Notes: Figure charts the estimated coefficient on public opinion shift on party position shifts over values of the economic globalization index, as provided by Table 1 Model 2 estimates. The globalization index is rescaled from 0-100 to 0-1. Dashed lines report $90 \%$ confidence intervals. 
Figure 3. Effect of Public Opinion Shift on Party Shift Conditional on Economic Globalization, CSES-Based Sample

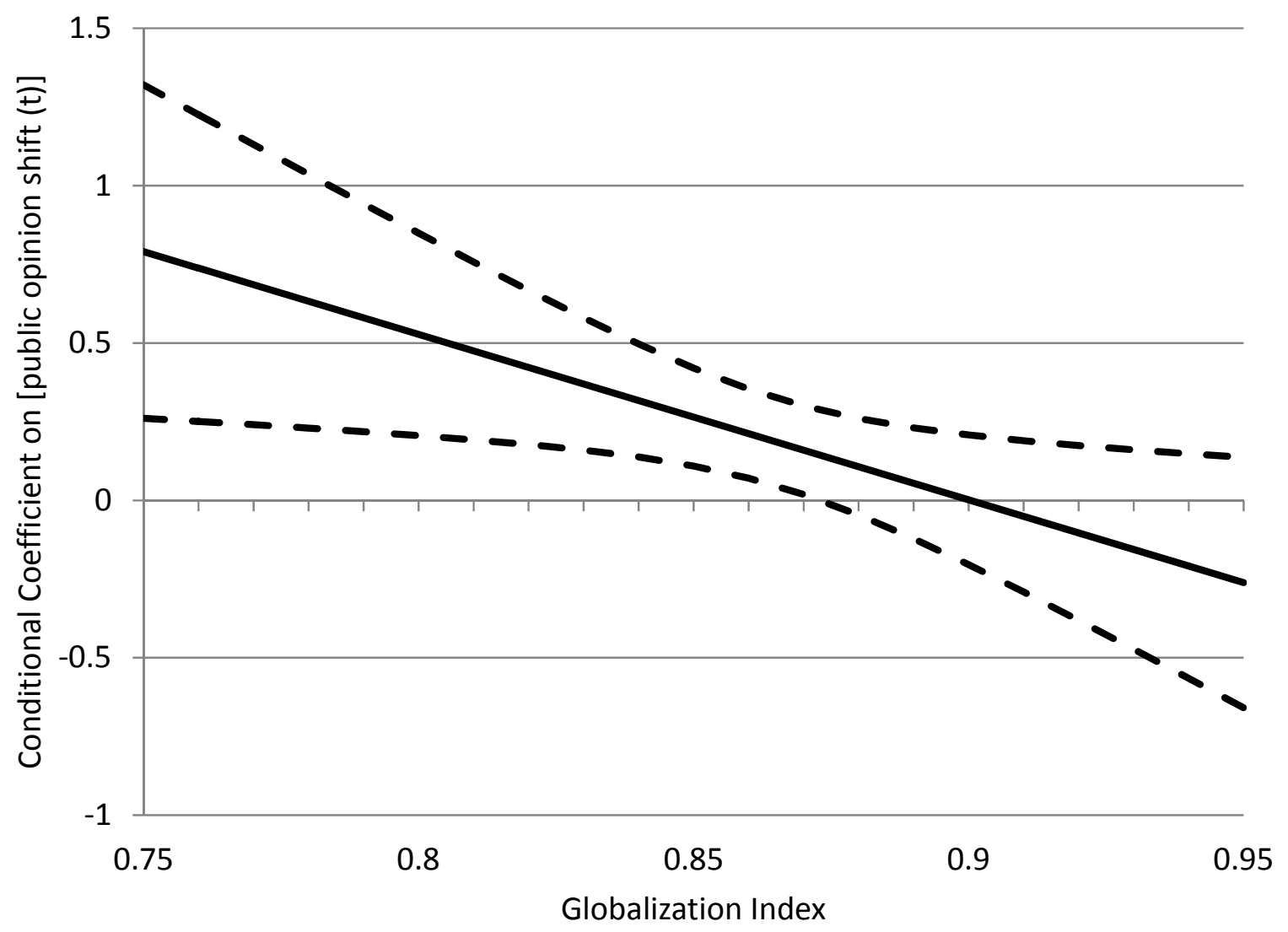

Notes: Figure charts the estimated coefficient on public opinion shift on party position shifts over values of the economic globalization index, as provided by Table 2 Model 9 estimates. The globalization index is rescaled from $0-100$ to $0-1$. Dashed lines report $90 \%$ confidence intervals. 
Table 1. Multivariate Analyses of Parties' Left-Right Policy Shifts in 18 Democracies, 1977-2009

\begin{tabular}{lccc}
\hline & All Parties & $\begin{array}{c}\text { Governing } \\
\text { experience } \\
\text { a }\end{array}$ & $\begin{array}{c}\text { No Governing } \\
\text { experience } \\
(2)\end{array}$ \\
\hline PUBLIC OPINION SHIFT $_{\mathrm{kt}}$ & $(1)$ & $3.65^{* *}$ & -1.42 \\
GLOBALIZATION $_{\mathrm{kt}}$ & $(1.13)$ & $(1.31)$ & $(1.08)$ \\
& $-1.45^{*}$ & -1.66 & -1.47 \\
PUBLIC OPINION SHIFT $_{\mathrm{kt}} \mathrm{x}$ & $(0.84)$ & $(1.03)$ & $(0.93)$ \\
GLOBALIZATION $_{\mathrm{kt}}$ & -0.77 & $-4.55^{* *}$ & 1.75 \\
GROWTH $_{\mathrm{kt}}$ & $(1.44)$ & $(1.60)$ & $(1.39)$ \\
& $0.03^{* *}$ & 0.02 & $0.03^{* *}$ \\
PARTY SHIFT $_{\mathrm{jkt}-1}$ & $(0.01)$ & $(0.02)$ & $(0.01)$ \\
& $-0.45^{* *}$ & $-0.39^{* *}$ & $-0.50^{* *}$ \\
Constant $^{*}$ & $(0.05)$ & $(0.07)$ & $(0.07)$ \\
$N$ & 0.75 & 0.47 & -0.14 \\
$R^{2}$ & $(0.60)$ & $(0.91)$ & $(0.81)$ \\
\hline
\end{tabular}

Notes. Dependent variable is PARTY SHIFT ${ }_{\mathrm{jkt} .}$ Robust standard errors clustered by election are in parentheses. ${ }^{*} \mathrm{p}<.10,{ }^{*} \mathrm{p}<.05$, two-tailed test (unconditional estimates); The estimates of public opinion and party position have been recalibrated to a $0-10$ scale. The models are estimated with country-specific intercepts.

a. "Governing experience" refers to those parties in the dataset which have experience as the largest partner in a governing coalition or have governed with a single party majority or minority. 
Table 2. Multivariate Analyses of Left-Right Policy Shifts for Parties with Governing Experience, Additional Models

\begin{tabular}{|c|c|c|c|c|c|c|c|c|c|}
\hline & $\begin{array}{c}\text { Shifts } \\
\text { in Glob. } \\
(1)\end{array}$ & $\begin{array}{l}\text { KOF } \\
\text { Flows } \\
(2)\end{array}$ & $\begin{array}{c}\mathrm{KOF} \\
\text { Restrictions } \\
\text { (3) }\end{array}$ & $\begin{array}{l}\text { Trade } \\
\text { (4) }\end{array}$ & $\begin{array}{c}\text { Election } \\
\text { Year control } \\
(5)\end{array}$ & $\begin{array}{l}\text { Detrended } \\
\text { globaliza- } \\
\text { tion } \\
(6)\end{array}$ & $\begin{array}{c}\text { EU Member } \\
\text { States } \\
(7)\end{array}$ & $\begin{array}{l}\text { Significant } \\
\text { Shifts } \\
(8)\end{array}$ & $\begin{array}{c}\text { CSES-based } \\
\text { sample } \\
\text { (9) }\end{array}$ \\
\hline $\begin{array}{l}\text { PUBLIC OPINION } \\
\text { SHIFT }_{k t}\end{array}$ & $\begin{array}{l}3.62 * * \\
(1.40)\end{array}$ & $\begin{array}{l}1.95^{* *} \\
(0.89)\end{array}$ & $\begin{array}{l}6.76^{* *} \\
(1.91)\end{array}$ & $\begin{array}{c}0.78 \\
(0.53)\end{array}$ & $\begin{array}{l}3.48 * * \\
(1.30)\end{array}$ & $\begin{array}{c}0.03 \\
(0.26)\end{array}$ & $\begin{array}{l}4.23 * * \\
(1.23)\end{array}$ & $\begin{array}{l}4.85^{* *} \\
(1.92)\end{array}$ & $\begin{array}{l}4.73^{*} \\
(2.33)\end{array}$ \\
\hline GLOBALIZATION $_{\mathrm{kt}}$ & $\begin{array}{c}-1.79 * \\
(0.99)\end{array}$ & $\begin{array}{c}-1.28^{*} \\
(0.70)\end{array}$ & $\begin{array}{c}-0.92 \\
(1.18)\end{array}$ & $\begin{array}{l}-0.37 \\
(0.40)\end{array}$ & $\begin{array}{c}0.77 \\
(1.89)\end{array}$ & $\begin{array}{l}-0.17 \\
(2.07)\end{array}$ & $\begin{array}{l}-1.49 \\
(1.01)\end{array}$ & $\begin{array}{l}-1.93 \\
(1.61)\end{array}$ & $\begin{array}{c}-3.72 * \\
(2.18)\end{array}$ \\
\hline $\begin{array}{l}\text { PUBLIC OPINION } \\
\text { SHIFT }_{\mathrm{kt}} \mathrm{x} \\
\text { GLOBALIZATION }_{\mathrm{kt}}\end{array}$ & $\begin{array}{c}-4.57 * * \\
(1.71)\end{array}$ & $\begin{array}{c}-2.65^{* *} \\
(1.14)\end{array}$ & $\begin{array}{c}-7.79 * * \\
(2.22)\end{array}$ & $\begin{array}{l}-0.88^{*} \\
(0.47)\end{array}$ & $\begin{array}{c}-4.37 * * \\
(1.59)\end{array}$ & $\begin{array}{l}-4.05^{*} \\
(2.28)\end{array}$ & $\begin{array}{c}-4.97 * * \\
(1.50)\end{array}$ & $\begin{array}{c}-6.30 * * \\
(2.69)\end{array}$ & $\begin{array}{l}-5.26^{*} \\
(2.69)\end{array}$ \\
\hline$\Delta \mathrm{GROWTH}_{\mathrm{kt}}$ & $\begin{array}{c}0.02 \\
(0.02)\end{array}$ & $\begin{array}{c}0.02 \\
(0.02)\end{array}$ & $\begin{array}{c}0.02 \\
(0.02)\end{array}$ & $\begin{array}{c}0.02 \\
(0.02)\end{array}$ & $\begin{array}{c}0.01 \\
(0.02)\end{array}$ & $\begin{array}{c}0.02 \\
(0.02)\end{array}$ & $\begin{array}{c}0.01 \\
(0.02)\end{array}$ & $\begin{array}{c}0.04 \\
(0.03)\end{array}$ & $\begin{array}{c}-0.02 * * \\
(0.01)\end{array}$ \\
\hline PARTY SHIFT $_{\mathrm{jkt}-1}$ & $\begin{array}{c}-0.39 * * \\
(0.07)\end{array}$ & $\begin{array}{c}-0.39 * * \\
(0.07)\end{array}$ & $\begin{array}{c}-0.38 * * \\
(0.07)\end{array}$ & $\begin{array}{c}-0.41 * * \\
(0.07)\end{array}$ & $\begin{array}{c}-0.40^{* *} \\
(0.07)\end{array}$ & $\begin{array}{c}-0.39 * * \\
(0.07)\end{array}$ & $\begin{array}{c}-0.35^{* *} \\
(0.08)\end{array}$ & $\begin{array}{c}-0.54 * * \\
(0.09)\end{array}$ & \\
\hline$\Delta$ GLOBALIZATION $_{\mathrm{kt}}$ & $\begin{array}{l}3.57^{*} \\
(2.07)\end{array}$ & & & & & & & & \\
\hline $\mathrm{YEAR}_{\mathrm{kt}}$ & & & & & $\begin{array}{c}-0.02 * \\
(0.01)\end{array}$ & & & & \\
\hline Constant & $\begin{array}{l}1.73^{*} \\
(0.97)\end{array}$ & $\begin{array}{c}0.09 \\
(0.59)\end{array}$ & $\begin{array}{l}-0.16 \\
(1.08)\end{array}$ & $\begin{array}{l}-0.60 \\
(0.54)\end{array}$ & $\begin{array}{l}38.59^{*} \\
(20.08)\end{array}$ & $\begin{array}{c}-0.98^{* *} \\
(0.16)\end{array}$ & $\begin{array}{c}0.34 \\
(0.88)\end{array}$ & $\begin{array}{c}1.69 \\
(1.31)\end{array}$ & $\begin{array}{l}3.61^{*} \\
(1.77)\end{array}$ \\
\hline$N$ & 252 & 252 & 252 & 270 & 252 & 252 & 218 & 156 & 78 \\
\hline$R^{2}$ & .25 & .24 & .24 & .19 & .25 & .22 & .23 & .33 & .18 \\
\hline
\end{tabular}

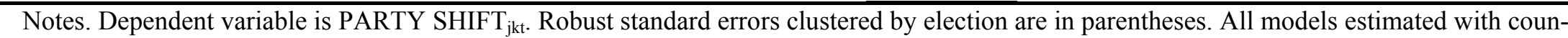
try-specific intercepts. ${ }^{*} \mathrm{p}<.10,{ }^{* *} \mathrm{p}<.05$, two-tailed test, unconditional coefficients. 